\title{
COMPARTMENT PRESSURES AFTER INTRAMEDULLARY NAILING OF THE TIBIA
}

\author{
M. M. MCQUEEN. J. CHRISTIE, C. M. COURT-BROWN \\ From the Royal Infirmary and Princess Margaret Rose Hospital, Edinburgh
}

\begin{abstract}
Intracompartmental pressures of 66 patients with 67 tibial fractures treated by intramedullary nailing were monitored. There was no difference in the pressures recorded between the different Tscherne fracture types, between open and closed fractures, between low energy and high energy injuries or between fractures dealt with early and those not treated until more than $\mathbf{2 4}$ hours after injury. The overall incidence of acute compartment syndrome was $1.5 \%$. No patient developed any sequelae of compartment syndrome.

We conclude that intramedullary nailing does not increase the incidence of acute compartment syndrome in tibial fractures and that delay does not reduce the risk of raised compartment pressures.
\end{abstract}

Closed intramedullary nailing is now established as a satisfactory method of managing femoral fractures, but it has not yet been generally accepted for the management of tibial fractures, despite reports of excellent results (Bone and Johnson 1986; Hindley 1988; Court-Brown, Christie and McQueen 1990). One reason for concern is the possibility that nailing might increase soft tissue swelling and precipitate an acute compartment syndrome. Indeed some authors (Donald and Seligson 1983; Bone and Johnson 1986) recommend delaying surgery for up to seven days in order to allow the acute soft tissue swelling to subside. This present study documents the effect of reamed intramedullary nailing of the tibia on intracompartmental pressures.

\section{MATERIALS AND METHOD}

Between April 1986 and October 1988, 66 patients admitted to the Royal Infirmary of Edinburgh with 67 tibial diaphyseal fractures were treated by intramedullary nailing and underwent intracompartmental pressure monitoring. The patients were recruited consecutively, provided the equipment and experienced personnel were available. There were 51 males and 15 females with an

M. M. McQueen, FRCS Ed(Orth), Senior Lecturer

C. M. Court-Brown, MD, FRCS Ed(Orth), Senior Lecturer

University of Edinburgh, Department of Orthopaedic Surgery, Princess

Margaret Rose Orthopaedic Hospital, Edinburgh EH 107 ED, Scotland.

J. Christie, FRCS Ed, Consultant Orthopaedic Surgeon

Orthopaedic Trauma Unit, Royal Infirmary of Edinburgh, Lauriston Place, Edinburgh EH3 9YW. Scotland.

Correspondence should be sent to Miss M. M. McQueen.

(C) 1990 British Editorial Society of Bone and Joint Surgery $0301-620 X / 90 / 3134 \$ 2.00$

J Bone Joint Surg [ Br] 1990; 72-B: 395-7.
Table I. Types and numbers of closed fractures

\begin{tabular}{llc}
\hline $\begin{array}{l}\text { Tscherne } \\
\text { grade }\end{array}$ & Definition & Number \\
\hline C0 & $\begin{array}{l}\text { Simple fracture configuration with little or no soft } \\
\text { tissue injury. }\end{array}$ & 9 \\
C1 & $\begin{array}{l}\text { Superficial abrasion. Mild to moderately severe } \\
\text { fracture configuration. }\end{array}$ & 30 \\
C2 & $\begin{array}{l}\text { Deep contaminated abrasion with local damage to } \\
\text { skin or muscle. Moderately severe to severe } \\
\text { fracture configuration. }\end{array}$ & 15 \\
C3 & $\begin{array}{l}\text { Extensive contusion or crushing of skin or } \\
\text { destruction of muscle. Severe fracture. }\end{array}$ & 4 \\
\hline
\end{tabular}

average age of 31 years (range 16 to 81 ). In 24 patients the fracture was sustained at sport and the same number occurred following road accidents ; 15 were injured by a simple fall, one fell from a height and two were assaulted. We used Tscherne's classification (Oestern and Tscherne 1984) for closed fractures and Gustilo's grading system (Gustilo and Anderson 1976) for open fractures. There were 58 closed fractures whose Tscherne classifications are detailed in Table $\mathrm{I}$. There were nine open fractures, seven being Gustilo type 1 and two type 2 .

Operative delay varied depending on the clinical state of the patient and the availability of theatre time: 30 patients were operated on and had compartment monitoring instituted within 24 hours of injury; in 27 there was a delay of more than 24 hours. Six of these delayed cases had had monitoring instituted on admission but their operation was delayed for more than 24 hours: pre-operative pressures were therefore recorded on these patients.

All patients underwent identical procedures. Traction was applied to the injured limb through a calcaneal pin. Prior to nailing and under sterile conditions a 20 
gauge $15 \mathrm{~cm}\left(6^{\prime \prime}\right)$ CVP catheter was modified at its tip by cutting two slits. This was inserted into the anterior compartment and connected to a transducer (S \& W System 8000 , Simonsen \& Weel Ltd, Kent) and chart recorder (BBC Goerz Metrawate Electroplan, Herts). The medullary canal was then reamed and intramedullary nailing proceeded as normal. After operation soft dressings were placed on the limb; no patient needed plaster. The limb was rested on one pillow and compartment monitoring was continued for 24 to 36 hours depending on the patient's clinical condition and the intracompartmental pressure.

All patients were reviewed for evidence of any sequelae of compartment syndrome. The follow-up time ranged from five months to one year with a mean of 11.5 months.

\section{RESULTS}

All the cases showed a similar pattern of pressure changes during the operative procedure. There were temporary rises in pressure during reaming, shown by peaks on the recording chart. Although high levels could be reached, the highest being $180 \mathrm{mmHg}$, these were always transient and the pressure fell back to its original level within seconds of removing the reamer. The traction applied to the leg for nailing tended to increase the compartment pressure but again this immediately dropped with the release of traction. The normal postoperative progress was for the compartment pressure to diminish gradually over 24 to 36 hours. There were no complications attributable to monitoring.

The compartment pressures of all 67 cases were analysed and Table II shows that the peri- and postoperative pressures were very similar in the four Tscherne types. There was no statistical difference between the groups and the gradual downward postoperative trend can be seen. The pressures recorded in the open fractures are very similar to those in the closed group. In the six patients with pre-operative pressure measurements the mean pre-operative pressure was $19 \mathrm{mmHg}$.

The effect of delaying the operative procedure is illustrated in Table III which shows a very small overall decrease in those patients who had surgery delayed for more than 24 hours. The differences are not statistically

Table II. Mean pressures $(\mathrm{mmHg} \pm$ s.d. $)$ related to fracture type

\begin{tabular}{lllll}
\hline \multirow{2}{*}{$\begin{array}{l}\text { Tscherne } \\
\text { type }\end{array}$} & Peri-operative & 1st 12 hours & 2nd 12 hours & 3rd 12 hours \\
\cline { 3 - 5 } C0 & $42 \pm 17.5$ & $30 \pm 10$ & $26 \pm 9.0$ & $25 \pm 4.3$ \\
C1 & $32 \pm 10.0$ & $27 \pm 8.4$ & $23 \pm 6.7$ & $20 \pm 6.5$ \\
C2 & $32 \pm 18.8$ & $22 \pm 10.1$ & $22 \pm 9.1$ & $25 \pm 5.0$ \\
C3 & $43 \pm 17.8$ & $30 \pm 8.9$ & $26 \pm 8.6$ & - \\
Open & $32 \pm 12.3$ & $29 \pm 10.6$ & $25 \pm 11.9$ & $24 \pm 8.5$ \\
\hline
\end{tabular}

Table III. Mean pressures $(\mathrm{mmHg} \pm$ s.d.) related to operative delay

\begin{tabular}{llllll}
\hline & & \multicolumn{4}{l}{ Postoperative } \\
\cline { 3 - 6 } $\begin{array}{l}\text { Delay } \\
\text { (hr) }\end{array}$ & $\begin{array}{l}\text { Number of } \\
\text { fractures }\end{array}$ & Peri-operative & $\begin{array}{l}\text { 1st } \\
\text { 12 hours }\end{array}$ & $\begin{array}{l}\text { 2nd } \\
\text { 12 hours }\end{array}$ & $\begin{array}{l}\text { 3rd } \\
\text { 12 hours }\end{array}$ \\
\hline$<24$ & 30 & $35 \pm 14.0$ & $28 \pm 10.8$ & $25 \pm 8.0$ & $25 \pm 4.0$ \\
$>24$ & 37 & $32 \pm 15.8$ & $27 \pm 8.4$ & $23 \pm 8.9$ & $22 \pm 7.7$ \\
\hline
\end{tabular}

Table IV. Mean pressures $(\mathrm{mmHg} \pm$ s.d.) related to nature of the injury

\begin{tabular}{llllll}
\hline & & & \multicolumn{3}{l}{ Postoperative } \\
\cline { 3 - 6 } $\begin{array}{l}\text { Energy level } \\
\text { of injury }\end{array}$ & $\begin{array}{l}\text { Number of } \\
\text { fractures }\end{array}$ & Peri-operative & $\begin{array}{l}\text { 1st } \\
\mathbf{1 2} \text { hours }\end{array}$ & $\begin{array}{l}\text { 2nd } \\
\mathbf{1 2} \text { hours }\end{array}$ & $\begin{array}{l}\text { 3rd } \\
\text { 12 hours }\end{array}$ \\
\hline High & 27 & $30 \pm 14.0$ & $26 \pm 8.6$ & $23 \pm 6.5$ & $22 \pm 4.3$ \\
Low & 40 & $36 \pm 15.8$ & $28 \pm 9.9$ & $24 \pm 4.4$ & $23 \pm 5.0$ \\
\hline
\end{tabular}

significant. The cases were also divided into high energy injuries (road accidents and falling from more than two metres) and low energy injuries (simple falls or football injuries). Again the mean compartment pressures were not significantly different (Table IV).

Only one patient developed an acute compartment syndrome (an incidence of $1.5 \%$ ). This patient was a 19 . year-old man who was injured at football and had a Tscherne type $\mathrm{Cl}$ fracture treated by closed intramedullary nailing six hours after admission. His peri-operative compartment pressure was $33 \mathrm{mmHg}$, with a diastolic blood pressure of $90 \mathrm{mmHg}$. Immediately after operation the anterior compartment pressure was $35 \mathrm{mmHg}$ and this gradually increased over the next six hours to $85 \mathrm{mmHg}$. At this stage he had no clinical features of acute compartment syndrome. A four-compartment fasciotomy was carried out through double incisions and the clinical findings confirmed a compartment syndrome in the anterior compartment; there was no visible muscle necrosis. After fasciotomy of the anterior compartment the pressure dropped to $15 \mathrm{mmHg}$. Post-fasciotomy monitoring was continued in the anterior compartment for 12 hours and the pressure remained at $10 \mathrm{mmHg}$. The wounds were covered by split skin grafts five days after fasciotomy. The patient was in hospital for 12 days, was weight-bearing at four weeks from injury and was back at full activity including sport at 12 weeks. Fracture union was recorded at 15 weeks after injury. One year after injury he had no deformity and had lost $5^{\circ}$ of ankle dorsiflexion.

No patient in this series developed any sequelae of compartment syndrome.

\section{DISCUSSION}

This study demonstrates clearly that intramedullary nailing of the tibia does not cause any increase in the incidence of acute compartment syndrome following tibial fracture. We have previously reported an incidence 
of $1 \%$ of acute compartment syndrome in a retrospective review of closed and type I open tibial fractures treated in this centre (Court-Brown and McQueen 1987). The $1.5 \%$ incidence in our present series is similar and compares favourably with the experience of others reporting on tibial fractures managed in plaster (DeLee and Stiehl 1981). Halpern and Nagel (1980) also report very similar compartmental pressures in 20 patients with tibial fractures treated in plaster.

Rorabeck and McKenzie (1985) state that compartment syndrome can occur as a complication of closed intramedullary nailing secondary to traction, manipulation and reaming. We challenge this statement on the basis of the low incidence in our series. Nor did any of our patients develop any late sequelae of compartment syndrome; this contrasts with reported incidences of toe clawing and other sequelae ranging from $2 \%$ (Ellis 1958) to $10 \%$ (Owen and Tsimboukis 1967).

It has previously been stated that it is preferable to delay intramedullary nailing of the tibia for up to seven days in order to allow acute soft tissue swelling to diminish and thus reduce the risk of acute compartment syndrome (Donald and Seligson 1983; Bone and Johnson 1986; Hindley 1988). Our results show that delay has no influence on the compartment pressures after tibial nailing and that delay is unnecessary; our current practice is to perform tibial nailing at the first available opportunity.

It is generally believed that extensive comminution implying disruption of the interosseous membrane and fascia is sufficient to decompress the compartments and thus prevent the development of acute compartment syndrome (Rorabeck and Macnab 1976). Tscherne's classification of closed fractures is based on soft tissue injury and comminution (Table I) and assumes compartment disruption in the more severe gradings. We found that compartment pressures reached very similar levels in all the Tscherne groups, which suggests that they have an equal risk of acute compartment syndrome.

The suggestion that an open fracture decompresses itself has been challenged by DeLee and Stiehl (1981) who reported six cases of acute compartment syndrome following grade 2 open fractures, and by McQuillan and Nolan (1968) three of whose cases of acute compartment syndrome were open fractures. In our series there was no significant difference in the compartment pressures in closed and open fractures after tibial nailing; this supports the concept that an open fracture does not preclude the development of acute compartment syndrome.

The compartment pressures in high energy and low energy injuries were very similar in our series; this contrasts with the findings of Halpern and Nagel (1980) who found a mean increase of $12 \mathrm{mmHg}$ in patients involved in road accidents compared with patients whose fractures had resulted from a fall.

Delay in treatment is well established as a cause of poor outcome after compartment syndrome (McQuillan and Nolan 1968; Matsen and Clawson 1975; Rorabeck and Macnab 1976). Our case of acute compartment syndrome illustrates the value of compartment monitoring as an 'early warning system'. Impending or early established acute compartment syndrome, in experienced hands, can be diagnosed by compartment monitoring before the onset of significant symptoms and in our case early fasciotomy resulted in full function of the limb. It is our current practice to monitor all tibial fractures, provided that the equipment and experienced personnel are available.

No benefits in any form have been received or will be received from a commercial party related directly or indirectly to the subject of this article.

\section{REFERENCES}

Bone LB, Johnson KD. Treatment of tibial fractures by reaming and intramedullary nailing. J Bone Joint Surg [Am] 1986; 68-A: 877-87.

Court-Brown CM, Christie J, McQueen MM. Closed intramedullary tibial nailing. J Bone Joint Surg [Br] 1990; 72B:CBX.

Court-Brown C, McQueen M. Compartment syndrome delays tibial union. Acta Orthop Scand 1987; $58: 249-52$.

DeLee JC, Stiehl JB. Open tibia fracture with compartment syndrome. Clin Orthop 1981 ; 160:175-84.

Donald G, Seligson D. Treatment of tibial shaft fractures by percutaneous $K$ üntscher nailing: technical difficulties and a review of 50 consecutive cases. Clin Orthop 1983; $178: 64-73$.

Ellis H. Disabilities after tibial shaft fractures: with special reference to Volkmann's ischaemic contracture. J Bone Joint Surg [Br] 1958; 40-B:190-7.

Gustilo RB, Anderson JT. Prevention of infection in the treatment of one thousand and twenty-five open fractures of long bones: retrospective and prospective analysis. J Bone Joint Surg [Am] 1976 ; $58-\mathrm{A}: 453-8$.

Halpern AA, Nagel DA. Anterior compartment pressures in patients with tibial fractures. J Trauma 1980; 20:786-90.

Hindley CJ. Closed medullary nailing for recent fractures of the tibia. Injury 1988; 19:180-4.

Matsen FA III, Clawson DK. The deep posterior compartmental syndrome of the leg. J Bone Joint Surg [Am] 1975; 57-A:34-9.

McQuillan WM, Nolan B. Ischaemia complicating injury: a report of thirty-seven cases. J Bone Joint Surg [Br] 1968; 50-B:482-92.

Oestern HJ, Tscherne $H$. Pathophysiology and classification of soft tissue injuries associated with fractures. In: Tscherne $\mathrm{H}$, Gotzen $\mathrm{L}$, eds. Fractures with soft tissue injuries. Berlin, etc: SpringerVerlag, 1984:1-9.

Owen R, Tsimboukis B. Ischaemia complicating closed tibial and fibular shaft fractures. J Bone Joint Surg [Br] 1967; 49-B:268-75.

Rorabeck CH, Macnab I. Anterior tibial-compartment syndrome complicating fractures of the shaft of the tibia. J Bone Joint Surg [Am] 1976; 58-A :549-50.

Rorabeck CH, McKenzie FH. Vascular injuries and compartment syndromes associated with fractures of the femur and tibia. In: Seligson D, ed. Concepts in intramedullary nailing. Orlando, etc: Grune \& Stratton, 1985:101-20. 